Original Research Article

\title{
Evaluation of anti-nociceptive effect of venlafaxine in experimental animal model of mice
}

\author{
Sandeep Kumar Bandapati ${ }^{1}$, Karuna Sree Podila ${ }^{2} *$, Yadala Venkata Rao ${ }^{3}$
}

${ }^{1}$ Pharmacovigilance Physician, Vigi Medsafe, Hyderabad,

Telangana, India

${ }^{2}$ Department of Pharmacology, ESIC Medical College and

Hospital, Sanathnagar,

Hyderabad, Telangana, India

${ }^{3}$ Department of Pharmacology,

Kamineni Institute of Medical

Sciences, Narketpally,

Telangana, India

Received: 23 September 2019

Accepted: 11 November 2019

*Correspondence to:

Dr. Karuna Sree Podila,

Email: drpkarunasri@gmail.com

Copyright: (C) the author(s), publisher and licensee Medip Academy. This is an openaccess article distributed under the terms of the Creative Commons Attribution NonCommercial License, which permits unrestricted noncommercial use, distribution, and reproduction in any medium, provided the original work is properly cited.

\begin{abstract}
Background: Pain is an unpleasant sensation with varying subjective experience. Its management is always challenging for physicians particularly in case of chronic pain. Chronic pain and depression usually co-exist due to poor quality of life and increase in health care costs posing an individual to suffer from depression. Anti-depressants for pain management are being used successfully using since years. In this study venlafaxine, a newer antidepressant drug was evaluated for anti-nociceptive activity, tail immersion test an analgesic animal model of albino mice.
\end{abstract}

Methods: Randomly selected albino mice of either sex with reaction time of $<6$ seconds were included in the study and divided into 7 groups with 6 mice in each group. Grouping was done based on the drug received i.e., venlafaxine 15, 30 and $60 \mathrm{mg} / \mathrm{kg}$, tramadol 10 and $20 \mathrm{mg} / \mathrm{kg}$, control group (normal saline) and combination group venlafaxine $15 \mathrm{mg} / \mathrm{kg}+$ tramadol $10 \mathrm{mg} / \mathrm{kg}$. Drugs were administered by intra-peritoneal route.

Results: Venlafaxine (30 and $60 \mathrm{mg} / \mathrm{kg})$, tramadol $(20 \mathrm{mg} / \mathrm{kg}$ ) and combination group venlafaxine (15 mg/kg+tramadol $10 \mathrm{mg} / \mathrm{kg})$ has shown significant $(\mathrm{p}<0.001)$ increase in tail withdrawal latency compared to control group (normal saline) by tail immersion test. Venlafaxine potentiated anti-nociceptive activity of tramadol on concomitant administration with tramadol. Venlafaxine at $60 \mathrm{mg} / \mathrm{kg}$ has comparable anti-nociceptive effect to tramadol at $20 \mathrm{mg} / \mathrm{kg}$.

Conclusions: Venlafaxine at doses of 30 and $60 \mathrm{mg} / \mathrm{kg}$ is having antinociceptive effect, but less potent than tramadol.

Keywords: Venlafaxine, Tramadol, Tail immersion test

\section{INTRODUCTION}

Pain is "an unpleasant sensory and emotional experience associated with actual or potential tissue damage or described in terms of such damage" as defined by the taxonomy committee of International Association for the study of pain. There are several areas of the central nervous system that directly or indirectly, are activated by nociceptive inputs and involved in the central modulation of pain. These modulatory effects are largely mediated by descending monoaminergic pathways that utilize serotonin (5-HT), nor-epinephrine (NE) or dopamine. ${ }^{1}$ Selective serotonin reuptake inhibitors which are novel antidepressant drugs, act by increasing 5-HT levels and inhibit the release of transmitters carrying pain sensation, hence used in the management of pain, especially neuropathic. ${ }^{2}$ Venlafaxine is one of the newer antidepressant drugs belonging to the group of selective serotonin and nor-epinephrine reuptake inhibitors (SNRI). Several preclinical studies on anti-nociceptive effect of venlafaxine with their respective animal models of pain have shown positive results but over a variable 
dose range. Each animal model is created with specific methodology and results tend to vary largely with slight changes related to methodology. Therefore, it is essential that data from different models should be reported and interpreted in context of the specific pain model. Therefore, in this study, an attempt has been made to evaluate the anti-nociceptive activity of venlafaxine, and its combination with tramadol using tail immersion animal model in albino mice for screening analgesic drugs. Aim is to evaluate the anti-nociceptive effect of venlafaxine in three grading doses $(15,30$ and $60 \mathrm{mg} / \mathrm{kg})$ and in combination with tramadol (venlafaxine $15 \mathrm{mg} / \mathrm{kg}$ and tramadol $10 \mathrm{mg} / \mathrm{kg}$ ) on albino mice by tail immersion model for screening analgesics and also to compare the results with control (normal saline) and standard groups (tramadol $20 \mathrm{mg} / \mathrm{kg}$ ).

\section{METHODS}

\section{Place of study}

It was a pre-clinical randomized controlled study conducted in the Department of Pharmacology, Kamineni Institute of Medical Sciences, Narketpally, with prior permission of Institutional Animal Ethics Committee.

\section{Laboratory animals}

Healthy albino mice procured from National Institute of Nutrition, Hyderabad, were brought and kept in the Central Animal Holding area of KIMS, Narketpally and maintained at an ambient temperature of $25-35^{\circ} \mathrm{C}$ with food and water ad libitum. The procedures followed were as per the guidelines of Committee for the purpose of Control and Supervision of Experiments on Animals. Healthy albino mice of either sex, weighing 25-35 g were included in the study.

\section{Drugs}

Venlafaxine and tramadol used for the experiment were purchased from Sigma Aldrich pharmaceuticals and Dr Reddy's Laboratories Limited, respectively.

\section{Equipment}

The tail immersion test was performed using hot water bath.

\section{Study procedure}

\section{Screening of animals}

Laboratory albino mice were selected by process of randomization and those showing reaction times i.e., tail withdrawal latency, less than 6 seconds in tail immersion method, were included in the study. Screened animals were divided into 7 groups with 6 animals in each group. Tail withdrawal latency is the time duration from immersing the tail in hot water bath, which is maintained at $55 \pm 0.5^{\circ} \mathrm{C}$ temperature by using thermostat control, till the withdrawal of the tail from hot water bath (Figure 1).

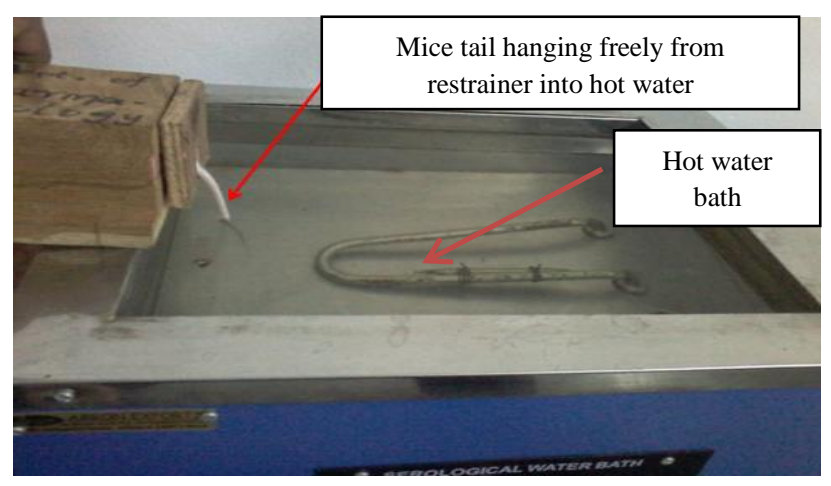

Figure 1: Tail immersion method of screening analgesic drugs using hot water bath.

Grouping of animals is shown in Table 1.

Table 1: Grouping of animals.

\begin{tabular}{|ll|}
\hline Group & Drug \\
\hline Group 1 (control) & Normal saline $(0.1 \mathrm{ml})$ \\
\hline Group 2 & Tramadol $10 \mathrm{mg} / \mathrm{kg}$ \\
\hline Group 3 & Tramadol $20 \mathrm{mg} / \mathrm{kg}$ \\
\hline Group 4 & Venlafaxine $15 \mathrm{mg} / \mathrm{kg}$ \\
\hline Group 5 & Venlafaxine $30 \mathrm{mg} / \mathrm{kg}$ \\
\hline Group 6 & Venlafaxine $60 \mathrm{mg} / \mathrm{kg}$ \\
\hline $\begin{array}{l}\text { Group 7 } \\
\text { (combination group) }\end{array}$ & $\begin{array}{l}\text { Venlafaxine } 15 \mathrm{mg} / \mathrm{kg} \text { and } \\
\text { tramadol } 10 \mathrm{mg} / \mathrm{kg}\end{array}$ \\
\hline
\end{tabular}

All the drugs were given intra-peritoneally. For the combination group i.e., group 7, both the drugs were administered simultaneously at different sites.

Anti-nociceptive effect of the drug was evaluated by tail withdrawal latency period by rodent model for pain. Tail withdrawal latency period, is the time interval between the tail immersion of the animal to the time it withdraws its tail from hot water bath. Also, the maximum possible effect in percentage was calculated for each group at 90 minutes.

Maximum possible effect $(\mathrm{MPE})$ in percentage $=$

$\frac{\text { Post drug latency- Pre drug latency }}{\text { Cutoff time- Pre drug latency }} \times 100$

\section{Procedure of the animal model for the determination of analgesic activity}

\section{Tail immersion test}

The mice were placed into individual restraining cages leaving the tail hanging out freely (Figure 1). The lower 5 $\mathrm{cm}$ portion of the tail was marked and immersed in a water bath containing freshly filled water at $50 \pm 5^{\circ} \mathrm{C}$. The 
tail withdrawal latency period was measured successively at $0,15,30,60$ and 90 minutes after drug administration. A withdrawal time of more than 6 seconds was regarded as a positive response for anti-nociception. The cut off time of the immersion is 15 seconds to prevent the temperature induced tail damage. After the test was done, the tail was carefully dried.

\section{Statistical analysis}

The data were tabulated and results were analyzed using the SPSS software (version 19) by calculating the mean, standard deviation, analysis of variance and post hoc test least significant difference (LSD). $\mathrm{P}<0.05$ was considered as significant.

\section{RESULTS}

In this study, anti-nociceptive effects of three graded doses of Venlafaxine $(15,30$ and $60 \mathrm{mg} / \mathrm{kg}$, i.p) and combination of venlafaxine $(15 \mathrm{mg} / \mathrm{kg})$ (i.p)+tramadol $(10 \mathrm{mg} / \mathrm{kg})$ (i.p) were compared with standard drug tramadol at an analgesic dose of $20 \mathrm{mg} / \mathrm{kg}$ (i.p) and control group normal saline (NS) at $0.1 \mathrm{ml}$ (i.p).

We observed that intra-peritoneal administration of venlafaxine increased the tail withdrawal latency period (sec., mean \pm SE) at doses of $30 \mathrm{mg} / \mathrm{kg}$ and $60 \mathrm{mg} / \mathrm{kg}$ and at time intervals of 30, 60 and 90 minutes in-comparison to control (NS) treatment group, indicating that venlafaxine produced anti-nociceptive effect in tail immersion test.
Intra-peritoneal (i.p) administration of known analgesic drug tramadol at the anti-nociceptive dose of $20 \mathrm{mg} / \mathrm{kg}$ increased the tail withdrawal latency at 30, 60 and 90 minutes interval compared to that observed for control group.

The tail withdrawal latency with venlafaxine $15 \mathrm{mg} / \mathrm{kg}$ as well as tramadol $10 \mathrm{mg} / \mathrm{kg}$ monotherapy at 30,60 and 90 minutes did not increase and results were similar to control, indicating that there was no anti-nociceptive effect at these doses of drugs.

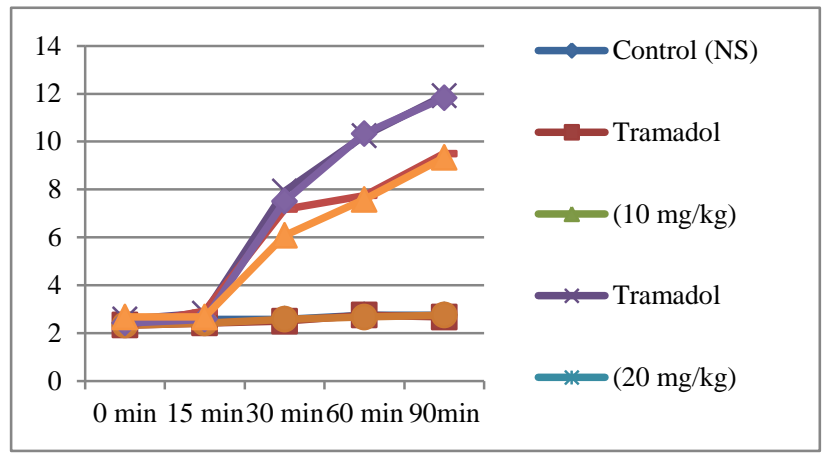

Figure 2: Trend of tail withdrawal latency period from 0 minutes to 90 minutes in Group 1 to Group 7.

Concomitant administration of low doses of both venlafaxine $(15 \mathrm{mg} / \mathrm{kg})$ and tramadol $(10 \mathrm{mg} / \mathrm{kg})$ increased the tail withdrawal latency at 30, 60 and 90 minutes in comparison to control, venlafaxine $15 \mathrm{mg} / \mathrm{kg}$ as well as tramadol $10 \mathrm{mg} / \mathrm{kg}$ monotherapy (Table 2, Figure 2).

Table 2: Tail withdrawal latency (in sec) in tail immersion test of animal model expressed in terms of mean \pm SEM at regular intervals.

\begin{tabular}{|c|c|c|c|c|c|}
\hline & $\begin{array}{l}\text { O min } \\
(\text { Mean } \pm \text { SEM })\end{array}$ & $\begin{array}{l}15 \min \\
(M e a n \pm \text { SEM })\end{array}$ & $\begin{array}{l}30 \text { min } \\
(\text { Mean } \pm \text { SEM })\end{array}$ & $\begin{array}{l}60 \text { min } \\
(\text { Mean } \pm \text { SEM })\end{array}$ & $\begin{array}{l}90 \text { min } \\
(\text { Mean } \pm \text { SEM })\end{array}$ \\
\hline Control (NS) & $2.42 \pm 0.15$ & $2.58 \pm 0.15$ & $2.58 \pm 0.15$ & $2.75 \pm 0.11$ & $2.75 \pm 0.15$ \\
\hline Tramadol (10 mg/kg) & $2.33 \pm 0.17$ & $2.42 \pm 0.15$ & $2.50 \pm 0.18$ & $2.75 \pm 0.11$ & $2.67 \pm 0.17$ \\
\hline Tramadol $(20 \mathrm{mg} / \mathrm{kg})$ & $2.58 \pm 0.15$ & $2.83 \pm 0.10$ & $7.92 \pm 0.27$ & $10.25 \pm 0.31$ & $11.92 \pm 0.33$ \\
\hline Venlafaxine $(15 \mathrm{mg} / \mathrm{kg})$ & $2.33 \pm 0.17$ & $2.42 \pm 0.15$ & $2.58 \pm 0.15$ & $2.67 \pm 0.17$ & $2.75 \pm 0.11$ \\
\hline Venlafaxine $(30 \mathrm{mg} / \mathrm{kg})$ & $2.33 \pm 0.17$ & $2.92 \pm 0.15$ & $7.17 \pm 0.21$ & $7.75 \pm 0.31$ & $9.50 \pm 0.18$ \\
\hline Venlafaxine $(60 \mathrm{mg} / \mathrm{kg})$ & $2.42 \pm 0.20$ & $2.58 \pm 0.15$ & $7.50 \pm 0.22$ & $10.33 \pm 0.25$ & $11.83 \pm 0.21$ \\
\hline $\begin{array}{l}\text { Venlafaxine+tramadol } \\
(15 \mathrm{mg} / \mathrm{kg}+10 \mathrm{mg} / \mathrm{kg})\end{array}$ & $2.67 \pm 0.17$ & $2.67 \pm 0.17$ & $6.08 \pm 0.20$ & $7.58 \pm 0.24$ & $9.33 \pm 0.25$ \\
\hline
\end{tabular}

Table 3: MPE of tail withdrawal latency period expressed in mean $\pm \mathrm{SE}$.

\begin{tabular}{|c|c|}
\hline Groups & MPE $($ Mean \pm SE $)$ \\
\hline Control (NS) & $4.23 \pm 2.10$ \\
\hline Tramadol (10 mg/kg) & $6.25 \pm 2.28$ \\
\hline Tramadol $(20 \mathrm{mg} / \mathrm{kg})$ & $96.80 \pm 2.16$ \\
\hline Venlafaxine $(15 \mathrm{mg} / \mathrm{kg})$ & $3.12 \pm 2.13$ \\
\hline Venlafaxine $(30 \mathrm{mg} / \mathrm{kg})$ & $61.80 \pm 3.44$ \\
\hline Venlafaxine $(60 \mathrm{mg} / \mathrm{kg})$ & $92.50 \pm 2.56$ \\
\hline Venlafaxine $15 \mathrm{mg} / \mathrm{kg}$ +tramadol $10 \mathrm{mg} / \mathrm{kg}$ & $63.68 \pm 3.04$ \\
\hline
\end{tabular}


Maximum possible effect (MPE) in tail withdrawal latency at 90 minutes was calculated for all the groups i.e., control, tramadol $(10 \mathrm{mg} / \mathrm{kg}, 20 \mathrm{mg} / \mathrm{kg})$, venlafaxine $(15,30$ and $60 \mathrm{mg} / \mathrm{kg})$ and combination treatment of venlafaxine $15 \mathrm{mg} / \mathrm{kg}$ and tramadol $10 \mathrm{mg} / \mathrm{kg}$ (Table 3).
MPE at 90 minutes in venlafaxine 30 and $60 \mathrm{mg} / \mathrm{kg}$, tramadol $20 \mathrm{mg} / \mathrm{kg}$, and the combination treatment of venlafaxine $15 \mathrm{mg} / \mathrm{kg}$ +tramadol $10 \mathrm{mg} / \mathrm{kg}$ groups was more and statistically significant in comparison to control group.

Table 4: Intergroup comparison of MPE of tail withdrawal latency by multiple comparison LSD test.

\begin{tabular}{|c|c|c|}
\hline Comparison between different groups & Mean difference & P value \\
\hline CTRL vs TRA 10 & -0.62 & $0.81(\mathrm{NS})$ \\
\hline CTRL vs TRA 20 & -72.61 & $0.0001^{* * *}$ \\
\hline CTRL vs VEN 15 & -0.64 & $0.80(\mathrm{~ns})$ \\
\hline CTRL vs VEN 30 & -53.87 & $0.0001^{* * *}$ \\
\hline CTRL vs VEN 60 & -72.17 & $0.0001^{* * *}$ \\
\hline CTRL vs VEN 15+TRA10 & -51.75 & $0.0001^{* * *}$ \\
\hline TRA 10 vs TRA 20 & -71.99 & $0.0001^{* * * *}$ \\
\hline TRA 10 vs VEN 15 & -0.02 & $0.99(\mathrm{~ns})$ \\
\hline TRA 10 vs VEN 30 & -53.25 & $0.0001^{* * *}$ \\
\hline TRA 10 vs VEN 60 & -71.55 & $0.0001^{* * *}$ \\
\hline TRA 10 vs VEN 15+TRA10 & -51.13 & $0.0001^{* * *}$ \\
\hline TRA 20 vs VEN 15 & 71.97 & $0.0001^{* * *}$ \\
\hline TRA 20 vs VEN 30 & 18.74 & $0.0001^{* * *}$ \\
\hline TRA 20 vs VEN 60 & 0.44 & $0.86(\mathrm{NS})$ \\
\hline TRA 20 vs VEN 15+TRA 10 & 20.86 & $0.0001^{* * *}$ \\
\hline VEN 15 vs VEN 30 & -53.23 & $0.0001^{* * *}$ \\
\hline VEN 15 vs VEN 60 & -71.53 & $0.0001^{* * *}$ \\
\hline VEN 15 vs VEN 15+TRA 10 & -51.11 & $0.0001^{* * *}$ \\
\hline VEN 30 vs VEN 60 & -18.30 & $0.0001^{* * *}$ \\
\hline VEN 30 vs VEN 15+TRA 10 & 2.12 & $0.42(\mathrm{NS})$ \\
\hline VEN 60 vs VEN 15+TRA 10 & 20.42 & $0.0001^{* * *}$ \\
\hline
\end{tabular}

Significance of $\mathrm{p}$ value $<0.001 * * * ; \mathrm{p}<0.01 * * ; \mathrm{p}<0.05^{*}, \mathrm{p}>0.05=$ Not significant (NS). CTRL: Control; TRA 10: Tramadol $10 \mathrm{mg} / \mathrm{kg}$; TRA 20: Tramadol $20 \mathrm{mg} / \mathrm{kg}$; VEN 15: Venlafaxine $15 \mathrm{mg} / \mathrm{kg}$; VEN 30: Venlafaxine 30mg/kg; VEN 60: Venlafaxine 60mg/kg; VEN 15+TRA 10: Venlafaxine $15 \mathrm{mg} / \mathrm{kg}+$ tramadol $10 \mathrm{mg} / \mathrm{kg}$.

Further intergroup comparison of MPE showed that antinociceptive effect of venlafaxine at $60 \mathrm{mg} / \mathrm{kg}$ is comparable with tramadol $20 \mathrm{mg} / \mathrm{kg}$. MPE in combination group receiving venlafaxine 15 $\mathrm{mg} / \mathrm{kg}$ +tramadol $10 \mathrm{mg} / \mathrm{kg}$ was significantly higher than in those receiving only venlafaxine at $15 \mathrm{mg} / \mathrm{kg}$ or tramadol at $10 \mathrm{mg} / \mathrm{kg}$ (Table 4).

\section{DISCUSSION}

Pain is an unpleasant sensation with varying subjective experiences and its treatment is always challenging for physicians. Chronic pain and depression usually co-exist and evidence suggests that chronic pain leads to depression and depression leads to pain. ${ }^{3}$ Depressive symptoms are commonly found in patients with chronic pain. ${ }^{4}$ Patients with chronic pain have a greater risk of becoming depressed, because chronic pain indicates greater severity with a poor quality of life thus posing an individual to suffer from depression as well as increase health care costs. ${ }^{5}$

Several antidepressants have been used successfully to treat psychological and physical symptoms of depression as well as chronic pain in non-depressed patients. Currently, tri-cyclic antidepressants (TCAs) are the most commonly used antidepressants for various types of chronic pain conditions. But their major drawback is their side effect profile. Venlafaxine, a novel antidepressant, has similar mode of action to that of TCAs, however, with favorable side effect profile. ${ }^{6,7}$ Proper assessment of analgesic potency and efficacy of venlafaxine by preclinical and clinical studies if resulted in positive outcome, can replace TCAs for treatment of such painful conditions.

The results of the present study have shown increase in tail withdrawal latency at 30,60 and 90 minutes intervals on administration of venlafaxine at doses of 30 and 60 $\mathrm{mg} / \mathrm{kg}$ indicating the anti-nociceptive effect of venlafaxine in tail immersion test. The results are in par with studies done by Jha et al in tail flick and writhing test analgesic models in albino mice and Sikka et al in tail flick model in mice who also reported the antinociceptive effect of venlafaxine but at slightly different doses (Table 5). ${ }^{8,9}$ 
Table 5: Comparison of tail flick latency period of previous studies with venlafaxine pre-treatment at 0 min and 60 min after treatment.

\begin{tabular}{|c|c|c|c|c|c|c|}
\hline & \multicolumn{2}{|c|}{ 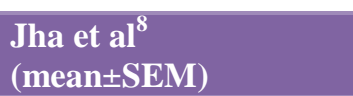 } & \multicolumn{2}{|c|}{$\begin{array}{l}\text { Sikka et al }{ }^{9}(\mathrm{n}=6) \\
(\text { mean } \pm \text { SEM })\end{array}$} & \multicolumn{2}{|c|}{$\begin{array}{l}\text { Present study }(\mathrm{n}=6) \\
(\text { mean } \pm \text { SEM) }\end{array}$} \\
\hline & 0 min & $60 \mathrm{~min}$ & 0 min & $60 \mathrm{~min}$ & 0 min & $60 \mathrm{~min}$ \\
\hline Venlafaxine 10 mg/kg & $3.73 \pm 0.33$ & $5.6 \pm 0.66$ & & & & \\
\hline Venlafaxine $22.5 \mathrm{mg} / \mathrm{kg}$ & $3.41 \pm 0.06$ & $5.86 \pm 0.05$ & & & & \\
\hline Venlafaxine 15 mg/kg & & & & & $2.33 \pm 0.17$ & $2.67 \pm 0.17$ \\
\hline Venlafaxine $30 \mathrm{mg} / \mathrm{kg}$ & & & 1.08 & $2.33 \pm 1.21$ & $2.33 \pm 0.17$ & $7.75 \pm 0.31$ \\
\hline Venlafaxine $50 \mathrm{mg} / \mathrm{kg}$ & & & 1.33 & $9.41 \pm 0.46$ & & \\
\hline Venlafaxine $60 \mathrm{mg} / \mathrm{kg}$ & & & & & $2.42 \pm 0.20$ & $10.33 \pm 0.25$ \\
\hline $\begin{array}{l}\text { Venlafaxine } 15 \\
\mathrm{mg} / \mathrm{kg} \text { +tramadol } 10 \mathrm{mg} / \mathrm{kg}\end{array}$ & & & & & $2.67 \pm 0.17$ & $7.58 \pm 0.24$ \\
\hline
\end{tabular}

Combination treatment of low doses of both venlafaxine $15 \mathrm{mg} / \mathrm{kg}$ and tramadol $10 \mathrm{mg} / \mathrm{kg}$ increased the tail withdrawal latency at 30,60 and 90 minutes in comparison to control group or when venlafaxine at 15 $\mathrm{mg} / \mathrm{kg}$ or tramadol at $10 \mathrm{mg} / \mathrm{kg}$ were administered alone.

Calculated MPE of tail withdrawal latency at 90 minutes suggested that intra-peritoneal administration of venlafaxine at 30 and $60 \mathrm{mg} / \mathrm{kg}$, tramadol at $20 \mathrm{mg} / \mathrm{kg}$ and combination treatment of venlafaxine $15 \mathrm{mg} / \mathrm{kg}$ and tramadol $10 \mathrm{mg} / \mathrm{kg}$ can produce significant antinociceptive effect in the tail immersion test model of albino mice. Further intergroup comparisons of MPE have shown that anti-nociceptive effect of venlafaxine at $60 \mathrm{mg} / \mathrm{kg}$ was comparable with tramadol at $20 \mathrm{mg} / \mathrm{kg}$ indicating that venlafaxine is less potent than tramadol. MPE in combination group with venlafaxine $15 \mathrm{mg} / \mathrm{kg}$ and tramadol $10 \mathrm{mg} / \mathrm{kg}$ was significantly higher than that with venlafaxine at $15 \mathrm{mg} / \mathrm{kg}$ or tramadol at $10 \mathrm{mg} / \mathrm{kg}$ when administered alone. This indicates that venlafaxine can potentiate anti-nociceptive effect of tramadol. Thus by combining low doses of both the drugs, adverse effects due to high doses of single administration of these drugs can be reduced. Jha et al, Wrzosek et al and Uyar et al have also reported potentiation of anti-nociceptive effect of tramadol with venlafaxine in animal models of pain. ${ }^{8,10,11}$ The dose at which anti-nociceptive activity of the drugs observed in this study was slightly different compared to that observed in other studies.

Descending 5-HT and NE pathways are known to have analgesic action by inhibiting pain causing afferent impulses. The anti-nociceptive effect of venlafaxine might be due to 5-HT and NE reuptake inhibiting property, leading to NE/5-HT accumulation. In addition, it has opioid like activity also. However, the mechanism of action of the drug was not studied in present study. It was observed that venlafaxine is having anti-nociceptive activity at doses of 30 and $60 \mathrm{mg} / \mathrm{kg}$ and in combination i.e., venlafaxine $15 \mathrm{mg} / \mathrm{kg}$ and tramadol $10 \mathrm{mg} / \mathrm{kg}$.

\section{CONCLUSION}

Present study suggests that venlafaxine, a known SNRI, has anti-nociceptive activity, which was evaluated by tail immersion test in albino mice, an analgesic animal model. Venlafaxine is less potent anti-nociceptive agent than tramadol, and potentiates the anti-nociceptive activity of standard drug tramadol when both are given concomitantly in sub-standard doses. Further experimental and human studies are required to confirm the anti-nociceptive activity of venlafaxine.

Funding: No funding sources

Conflict of interest: None declared

Ethical approval: The study was approved by the Institutional Ethics Committee

\section{REFERENCES}

1. Mason P. Deconstructing endogenous pain modulations. J Neurophysiol. 2005;94(3):1659-63.

2. Kuhad A, Bishnoi M, Chopra K. Anti-nociceptive effect of duloxetine in mouse model of diabetic neuropathic pain. Indian J Exp Biol. 2009;47(3):1937.

3. Wise TN, Fishbain DA, Holder-Perkins V. Painful physical symptoms in depression: a clinical challenge. Pain Med. 2007;8(2):S75-82.

4. Lepine JP, Briley M. The epidemiology of pain in depression. Hum Psychopharmacol. 2004;19(S1):3-7.

5. Rayner L, Hotopf M, Petkova H, Matcham F, Simpson A, Mc Cracken LM. Depression in patients with chronic pain attending a specialised pain treatment centre: prevalence and impact on health care costs. Pain. 2016;157(7):1472-9.

6. Barkin RL, Schwer WA, Barkin SJ. Recognition and management of depression in primary care: a focus on the elderly. A pharmacotherapeutic overview of the selection process among the traditional and new antidepressants. Am J Ther. 2000;7(3):205-26.

7. Barkin RL. Attributes, and advantages of venlafaxine overlooked. Formular. 1998;33:74-5.

8. Jha PK, Mazumdar B, Bhatt JD. Analgesic activity of Venlafaxine and its interactions with Analgesic activity of Venlafaxine and its interactions with Tramadol, celecoxib and amlodipine in mice tramadol, celecoxib and amlodipine in mice. Indian $\mathbf{J}$ Pharmacol. 2006;38(3):181-4. 
9. Sikka P, Kaushik S, Kumar G, Kapoor S, Bindra VK, Saxena KK. Study of antinociceptive activity of SSRI (fluoxetine and escitalopram) and atypical antidepressants (venlafaxine and mirtazepine) and their interaction with morphine and naloxone in mice. J Pharm Bioall Sci. 2011;3:412-6.

10. Obara WI, Wordliczek J, Przewlocka B. Efficacy of Tramadol in combination with doxepin or Venlafaxine in inhibition of nociceptive process in the rat model of neuropathic pain: an isobolographic analysis. J Physiol Pharmacol. 2009;60(4):71-8.
11. Uyar M, Onal A, Uyar M, Dogru A, Soykan N. The antinociceptive effect of tramadol-venlafaxine combination on the paw withdrawal threshold in a rat model of neuropathic pain. Methods Find Exp Clin Pharmacol. 2003;25(5):361-5.

Cite this article as: Bandapati SK, Podila KS, Rao YV. Evaluation of anti-nociceptive effect of venlafaxine in experimental animal model of mice. Int J Basic Clin Pharmacol 2019;8:2598-603. 